\title{
Uji Resistensi Bakteri Karang Galaxea sp. dan Porites sp. terhadap Pestisida Triazofos
}

\author{
Muhammad Eka Darmawan Rafsanjani*, Agus Sabdono, Ali Djunaedi \\ Departemen IImu Kelautan, Fakultas Perikanan dan IImu Kelautan, Universitas Diponegoro \\ JI. Prof.H.Soedarto S.H, Tembalang,Semarang, Jawa Tengah 50275 Indonesia \\ *Corresponding author, e-mail : rfsnjn.387@gmail.com
}

\begin{abstract}
ABSTRAK: Kerusakan terumbu karang merupakan permasalahan serius di laut saat ini. Kerusakan tersebut disebabkan oleh beberapa faktor salah satunya penggunaan pestisida. Salah satu jenis pestisida yang digunakan para petani yaitu pestisida triazofos. Penggunaan pestisida triazofos di sektor pertanian akan meninggalkan residu dan terbawa ke perairan melalui sungai dan saluran air. Residu pestisida triazofos diduga dapat menyebabkan kerusakan ekosistem terumbu karang. Tujuan dari penelitian untuk mengetahui potensi resistensi karang Porites sp. dan Galaxea sp. terhadap pestisida triazofos dari Perairan Pulau Panjang, Jepara. Metode yang digunakan untuk pengambilan sampel adalah purposive sampling method, untuk memperoleh isolat bakteri yang berasosiasi dengan karang Porites sp. dan Galaxea sp., dan metode experimental laboratoris untuk uji resistensi isolat bakteri. Kurva regresi larutan standar dengan persamaan $y=0,0057 x+0,1088$ dipakai untuk menentukan konsentrasi pestisida triazofos. Nilai $R^{2}$ menunjukkan angka 0,8694 yang berarti secara umum data yang dihasilkan mempunyai validasi data yang baik. Konsentrasi pestisida triazofos digunakan dalam uji degradasi oleh bakteri sebesar $50 \mathrm{ppm}$. Nilai absorbansi yang dihasilkan sebanyak 0,5285 . Hasil uji menunjukkan seluruh isolat yang digunakan bersifat resisten terhadap pestisida triazofos yaitu PPP 11, PPP 9, GPP 6, PPP 1, GPP 7, GPP 4. Isolat PPP 11 memiliki persen degradasi tertinggi sebanyak 99,67\%, GPP 4 memiliki persen degradasi terenddah sebanyak 34,34\%. Disimpulkan bahwa isolat bakteri asosiasi karang Porites sp. dan Galaxea sp. memiliki resistensi terhadap pestisida triazofos.
\end{abstract}

Kata kunci: Uji resistensi, bakteri, pestisida, triaizofos

\section{Resistance test of Galaxea sp. and Porites sp. corals against triazophos pesticide}

ABSTRACT: Damage to coral reefs is a serious problem at sea at this time. The damage is caused by several factors, one of which is the use of pesticides. One type of pesticide used by farmers is the triazophos pesticide. The use of triazophos pesticides in the agricultural sector will leave residues and be carried into the waters through rivers and waterways. Triazophos pesticide residues are thought to cause damage to coral reef ecosystems. The purpose of this study is to determine the potential of coral resistance Porites sp. and Galaxea sp. against triazofos pesticides from Panjang Island waters, Jepara. The method used for sampling is purposive sampling method, to obtain bacterial isolates associated with Porites sp. and Galaxea sp., and spectrophotometric methods for testing bacterial isolate resistance. Standard solution regression curves with the equation $y=$ $0.0057 x+0.1088$ are used to determine the concentration of the triazophos pesticide. $R^{2}$ value indicates the number 0.8694 which means that in general the data generated has good data validation. The concentration of the triazofos pesticide used in the bacterial degradation test was $50 \mathrm{ppm}$. The absorbance value produced was 0.5285 . The test results showed that all isolates used were resistant to triazophos pesticides namely PPP 11, PPP 9, GPP 6, PPP 1, GPP 7, GPP 4. PPP 11 isolates had the highest degradation percentages of $99.67 \%$, GPP 4 had the lowest degradation percentages $34.34 \%$. It was concluded that the bacterial isolates of Porites sp. and Galaxea sp. has triazofos pesticide resistance.

Keywords: Resistance test, Bacteria, persticide, triazophos 


\section{PENDAHULUAN}

Terumbu karang merupakan ekosistem perairan yang khas terdapat di daerah tropis yang memiliki produktivitas dan keanekaragaman biota yang tinggi. Ekosistem terumbu karang mempunyai peranan penting bagi aspek ekologi, ekonomi, pariwisata dan pendidikan (Suharsono, 1996). Ekosistem terumbu karang ditinjau dari aspek ekologi memiliki fungsi sebagai sumber keanekaragaman hayati biota laut, sebagai tempat tinggal bagi biota laut, sebagai tempat mencari makan (feeding ground), sebagai tempat berpijah (spawning ground), sebagai daerah asuhan (nursery ground) serta tempat berlindung bagi biota laut lainnya. Ekosistem terumbu karang biasa dihidupi oleh beraneka ragam biota seperti 300 jenis karang, 200 jenis ikan dan berpuluh-puluh jenis moluska, crustacea, sponge, alga, lamun dan biota lainnya (Dahuri, 2000). Perairan Pulau Panjang merupakan salah satu perairan di Indonesia yang mempunyai ekosistem terumbu karang. Secara ekologi, ekosistem terumbu karang yang ada di Perairan Pulau Panjang mengalami interaksi secara langsung dengan aktivitas manusia salah satunya adalah kegiatan pertanian. Perairan Pulau Panjang merupakan daerah yang jaraknya cukup dekat dengan lahan pertanian dan sebagian besar digunakan untuk intensifikasi pertanian (Nugroho et al., 2015). Hal ini memungkinkan terjadinya pencemaran yang disebabkan oleh meningkatnya penggunaan pestisida. Penggunaan pestisida bertujuan untuk meningkatkan hasil produksi pertanian baik secara kualitatif maupun kuantitatif. Proses masuknya residu pestisida dari pertanian ke perairan yaitu dengan proses limpahan air dari petakan satu sawah akan dialirkan kepetakan sawah yang lain, dan seterusnya sampai akhirnya dibuang kembali ke sungai atau saluran irigasi yang sama. Masuknya pestisida ke dalam perairan melalui berbagai jalur, antara lain: buangan limbah perkotaan dan industri, limpasan dari areal persawahan, pencucian melalui tanah, penimbunan aerosol dan partikulat, curah hujan serta penyerapan dari fase uap antara fase udara-air (Taufik, 2011). Pernyataan Nybakken (1992) yang menyatakan kegiatan manusia secara langsung dapat menyebabkan kerusakan dan kematian terumbu melalui aktivitas penggalian dan pencemaran. Dampak yang ditimbulkan dari penggunaan pestisida yaitu akan menghasilkan residu yang tertinggal di tanah dan mengalir ke perairan. Munasik (2009).

Pencemaran dari berbagai senyawa halogen pada perairan Pulau Panjang yang disebabkan oleh meningkatnya penggunaan bahan pestisida, herbisida dan insektisida di dalam bidang pertanian, memungkinkan tidak berfungsinya dan menurunnya kualitas lingkungan yang sangat merugikan bagi keseimbangan ekosistem perairan pantai. Terdapat beberapa jenis pestisida yang digunakan oleh petani di wilayah Jepara, salah satunya adalah triazofos yang merupakan pestisida golongan organofosfat. Triazofos, insektisida organofosfat spektrum luas non-sistemik yang baru diperkenalkan dan digunakan untuk mengendalikan berbagai jenis populasi hama di bidang pertanian padi dan kapas di semua bagian dunia (Worthing dan Hanrce, 1991; Mingzing et al., 2003). Triazofos bersifat neurotoksik dan menyebabkan akumulasi neurotransmitter asetilkolin dalam sinaps yang mengakibatkan aliran sinyal neuromuskuler yang terus menerus menyebabkan kelumpuhan dan kematian serangga (Kamanyire dan karalliedde, 2004; Singh dan Rishi, 2005). Insektisida yang digunakan untuk berbagai macam keperluan mencapai sumber air, baik secara langsung atau tidak langsung melalui runoff dari bidang pertanian, penyemprotan, air hujan, air limbah dan limbah dari industri (Klein dan Alder, 2003). Hingga saat ini belum diketahui bakteri dari karang Porites sp. dan Galaxea sp. yang memiliki resistensi terhadap senyawa pestisida triazofos. Tujuan dari penelitian ini adalah unutk mengetahui potensi resistensi bakteri yang diisolasi dari karang Porites sp. dan Galaxea sp. dari Perairan Pulau Panjang, Jepara.

Penelitian lapangan yaitu berupa pengambilan sampel karang Porites sp. dan Galaxea sp. di Perairan Pulau Panjang, Jepara, Jawa Tengah. Pengambilan sampel menggunakan purposive sampling method yaitu metode pengambilan sampel yang dilakukan dengan mengambil subjek berdasarkan tujuan tertentu (Arikunto, 2006). Tujuan dari pengambilan sampel karang untuk mengetahui isolat bakteri yang berasosiasi dengan karang Porites sp. dan Galaxea sp. yang diduga memiliki resistensi terhadap pestisida triazofos. Tahap kedua menggunakan metode penelitian eksperimental laboratoris. Metode eksperimental laboratoris yaitu suatu metode penelitian yang berencana dalam lingkup laboratorium dengan tujuan untuk memperoleh atau memperluas fakta yang sudah ada sebelumnya (Arikunto, 2006). 


\section{MATERI DAN METODE}

Penentuan titik sampling dilakukan dengan berenang menggunakan skin dive. Titik sampling ditentukan dengan metode Manta Tow yaitu dengan cara berenang mengamati beberapa objek di sepanjang daerah sampling untuk menemukan objek yang menjadi target penelitian. Metode ini digunakan karena merupakan metode penilaian visual pada area yang luas dalam waktu yang cepat (Munasik, 2009). Setelah menemukan karang yang akan dijadikan sampel penelitian, kemudian sampel difoto menggunakan kamera underwater untuk dokumentasi. Koordinat lokasi dengan menggunakan Global Position System (GPS). Pengambilan sampel dilakukan pada koordinat S 06034'36.257"dan E $110^{0} 37^{\prime} 51.917$ ". Titik lokasi sampling dapat dilihat pada Gambar 1.

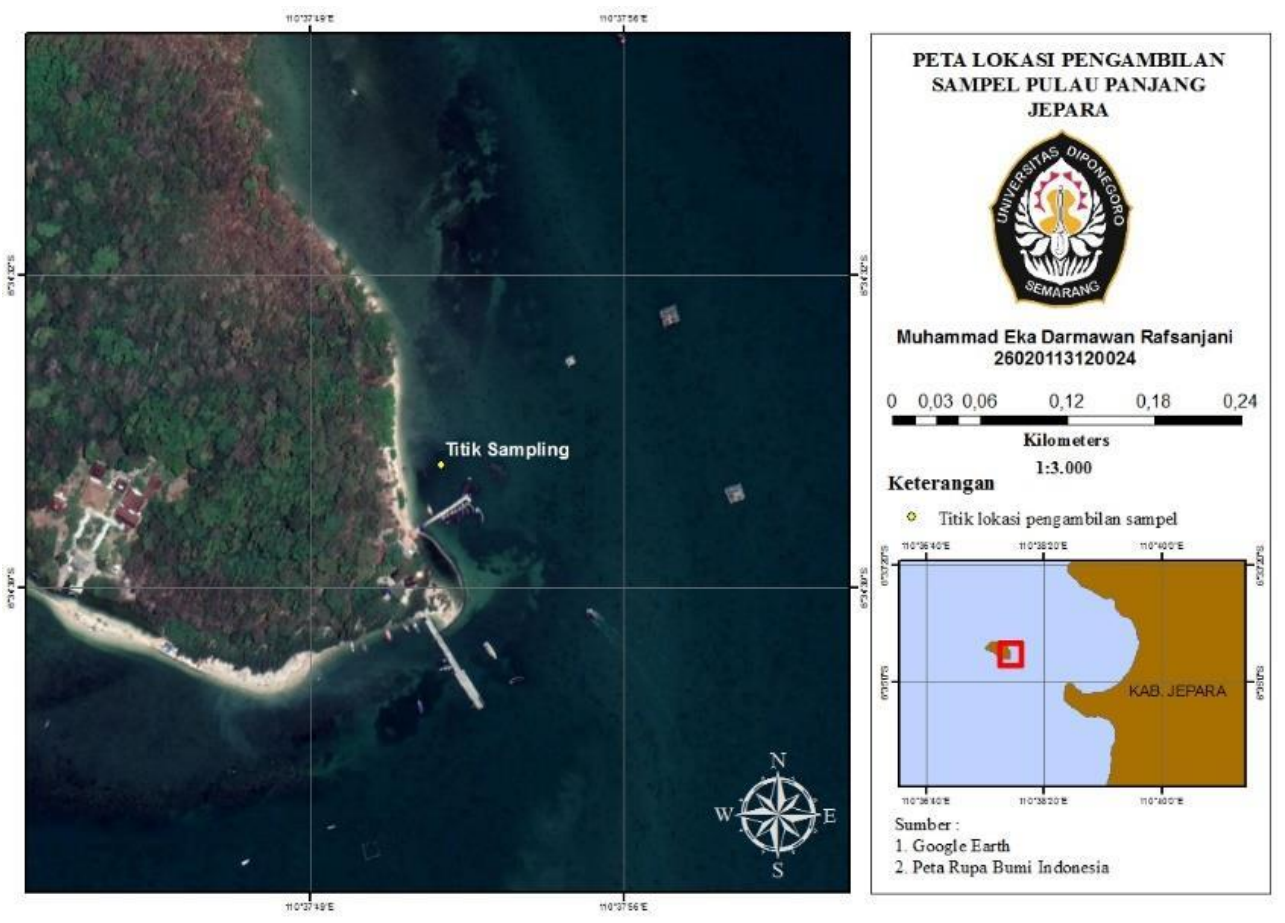

Gambar 1. Titik Sampling Lokasi Penelitian

Pengambilan sampel karang Porites sp dan Galaxea sp dilakukan dengan menggunakan skin dive pada kedalaman 1-2 m. Sampel jaringan karang diambil dengan menggunakan tatah dan palu, dengan cara menatah sebagian koloni karang untuk memotong sebagian jaringan (crapping). Kemudian sampel karang yang sudah dipotong dimasukkan ke cool box dan dipasang aerator untuk menyuplai oksigen agar karang tidak cepat stress serta dipasang termometer digital untuk memastikan agar suhu air yang ada pada cool box tidak mengalami peningkatan atau penurunan secara signifikan agar karang dapat bertahan hidup.

Uji resistensi isolat bakteri asosiasi karang Porites sp. dan Galaxea sp.meliputi kurva absorbansi triazofos, Kurva absorbansi pestisida dibuat dari masing-masing konsentrasi pestisida sebanyak (5, 10, 20, 30, 40, 50, 60, 70, 80, 90 dan 100 ppm) (M2) pada $20 \mathrm{~mL}$ (V2) media zobell cair. Stok pestisida dihitung sebagai (M1) dengan nilai 1000 ppm. Perhitungan volume pestisida pada setiap konsentrasi ditentukan dengan rumus M1.V1 = M2.V2. Larutan campuran dari zobell cair dan pestisida kemudian ditentukan nilai absorbansinya melalui pembuatan kurva dengan menggunakan spektrofotometer UV-Vis. Panjang gelombang yang digunakan pada pestisida triazofos yaitu $270 \mathrm{~nm}$. uji kualitatif degradasi pestisida, Isolat bakteri yang dibiakkan pada media zobell $2216 \mathrm{E}$ diuji resistensi terhadap triazofos, isolat bakteri tersebut diambil dengan menggunakan ose, kemudian diinokulasikan pada botol vial kaca berisikan $20 \mathrm{~mL}$ media NB yang telah dicampur dengan pestisida triazofos dengan konsentrasi 50 ppm. Tabung reaksi tersebut digoyang dengan kecepatan $120 \mathrm{rpm}$ dengan suhu ruangan $31^{\circ} \mathrm{C}$ selama 24 jam. Hasil dari inkubasi, kemudian diamati dengan menggunakan kontrol. Uji kuantitaif degradasi pestisida, Uji kuantitatif degradasi. 
pestisida triazofos dilakukan dengan cara mencampurkan larutan zobell cair dan pestisida terhadap isolat bakteri yang telah direkultur pada media miring. Kemudian campuran tersebut diinkubasi selama $3 \times 24$ jam. Kemudian sampel yang telah diinkubasi tersebut di sentrifuse dengan kecepatan 6000 rpm dalam waktu 5 menit. Hasil dari sentrifuse kemudian diambil bagian natant-nya dan kemudian diukur daya degradasinya menggunakan spektrofotometer UV - Vis dengan panjang gelombang $270 \mathrm{~nm}$. Persen degradasi pestisida dapat dihitung dengan rumus sebagai berikut.

$$
(A i-A f) / A i x 00 \%
$$

Keterangan : $\mathrm{Ai}=$ Konsentrasi awal; $\mathrm{Af}=$ Konsentrasi akhir

\section{HASIL DAN PEMBAHASAN}

Nilai absorbansi pestisida triazofos ditentukan menggunakan Spektrofotometer UV-Vis dengan panjang gelombang $270 \mathrm{~nm}$. Variasi konsentrasi pestisida triazofos yang digunakan adalah 5, 10, 20, $30,40,50,60,70,80,90$ dan 100 ppm. Hasil pengukuran dapat dilihat pada gambar 2, dan untuk nilai pengukuran absorbansi pestisida triazofos dapat dilihat pada Tabel 1.

Hasil pengamatan kualitatif resistensi bakteri terhadap pestisida menunjukkan bahwa semua isolat bakteri yang diuji bersifat resisten dan dapat tumbuh di media yang berisikan Zobell cair dan pestisida triazofos konsentrasi $50 \mathrm{ppm}$. Isolat bakteri terbaik ditunjukkan dengan indikator resistensi yang sangat keruh. Isolat bakteri dengan indikator resistensi yang sangat keruh yaitu GGP 7, GPP 9, PPP 1, PPP 2, PPP 9, PPP 11. Hasil uji kualitatif isolat bakteri dapat dilihat pada Tabel 2.

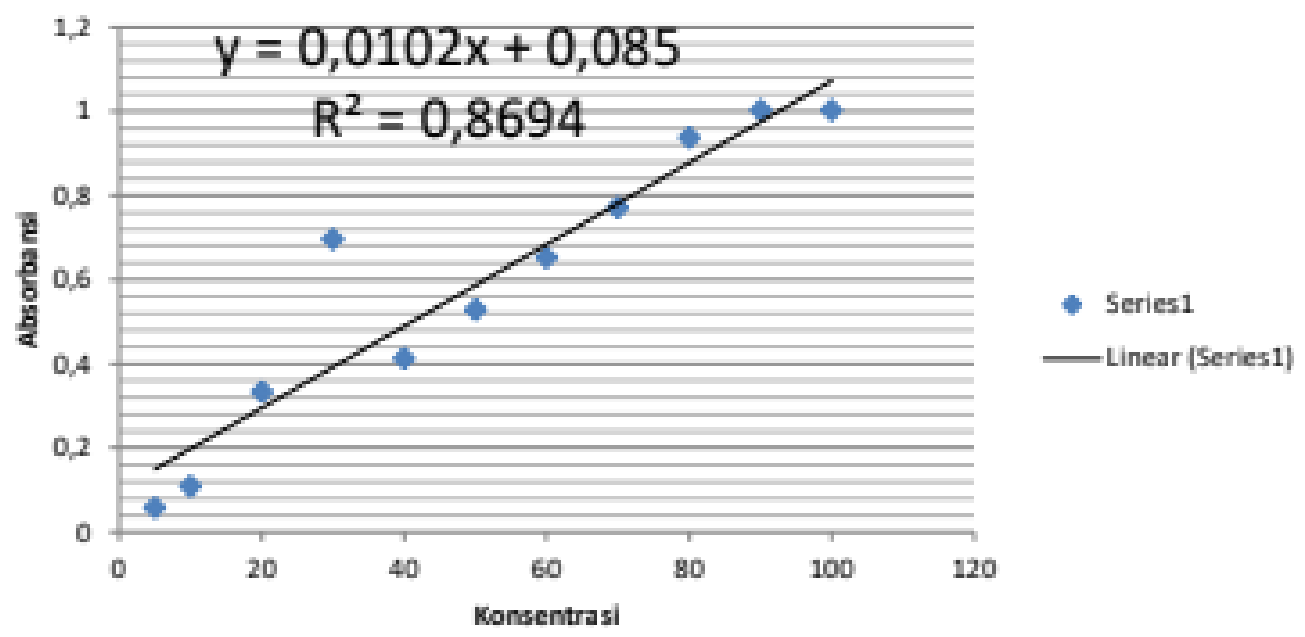

Gambar 2. Kurva Kalibrasi Standar Absorbansi Pestisida riazofos

Tabel 1. Tingkat Absorbansi Pestisida Triazofos

\begin{tabular}{cc}
\hline Konsentrasi Triazofos & Nilai Absorbansi \\
\hline $5 \mathrm{ppm}$ & 0,0574 \\
$10 \mathrm{ppm}$ & 0,1087 \\
$20 \mathrm{ppm}$ & 0,333 \\
$30 \mathrm{ppm}$ & 0,6962 \\
$40 \mathrm{ppm}$ & 0,412 \\
$50 \mathrm{ppm}$ & 0,5285 \\
$60 \mathrm{ppm}$ & 0,652 \\
$70 \mathrm{ppm}$ & 0,77 \\
$80 \mathrm{ppm}$ & 0,937 \\
$90 \mathrm{ppm}$ & 1,0021 \\
$100 \mathrm{ppm}$ & 1,0022 \\
\hline
\end{tabular}


Uji dilakukan terhadap pestisida triazofos 50 ppm. Isolat bakteri yang dapat mendegradasi pestisida triazofos dengan konsentrasi 50 ppm sebanyak 6 isolat yaitu isolat PPP 11, PPP 9, GPP 6, PPP 1, GPP 7, GPP 4. Hasil uji ditunjukkan pada tabel 9. Persentase degradasi isolat bakteri tertinggi adalah isolat bakteri PPP 11 dengan persen degradasi sebanyak 99,76\% sedangkan terendah adalah isolat bakteri GPP 4 dengan persen degradasi sebanyak 34,34\%. Persen degradasi isolat bakteri terhadap triazofos 50 ppm ada pada Tabel 3 .

Penentuan nilai absorbansi pestisida triazofos dilakukan dengan menggunakan metode Spetrofotometri UV-Vis. Panjang gelombang yang digunakan adalah $270 \mathrm{~nm}$. Metoda Spektrofotometri UV-Vis digunakan untuk menentukan konsentrasi larutan, dimana absorbsi sinar oleh larutan merupakan fungsi kosentrasi. Pada kondisi optimum, dapat dibuat hubungan linier secara langsung antara absorbsi larutan dan konsentrasi larutan tersebut. Penggunaan alat spektrofotometer UV-Vis untuk mengetahui nilai absorbansi pestisida triazofos disebabkan karena pestisida triazofos memiliki ikatan rangkap dan juga pasangan elektron bebas yang dapat mengalami transisi elektron (Permanasari 2011). Kurva regresi larutan standar dengan persamaan $\mathrm{y}=0,0057 \mathrm{x}+0,1088$ dipakai untuk menentukan konsentrasi pestisida triazofos. Nilai $\mathrm{R}^{2}$ menunjukkan angka 0,8694 yang berarti secara umum data yang dihasilkan mempunyai validasi data yang baik (Arfi \& Safni, 2015). Konsentrasi pestisida triazofos digunakan dalam uji degradasi oleh bakteri sebesar 50 ppm. Nilai absorbansi yang dihasilkan sebanyak 0,5285. Nilai absorbansi yang dihasilkan dari pestisida triazofos 50 ppm digunakan untuk menentukan persentase degradasi pestisida oleh bakteri.

Tabel 2. Hasil Skrining Resistensi Bakteri terhadap Pestisida Triazofos 50 ppm

\begin{tabular}{lll}
\hline No. & Nama Isolat & Indikator Resistensi Bakteri \\
\hline 1. & GPP 1 & + \\
2. & GPP 2 & + \\
3. & GPP 7 & ++ \\
4. & GPP 9 10 & ++ \\
5. & GPP 10 & + \\
6. & PPP 1 & ++ \\
7. & PPP 2 & ++ \\
8. & PPP 3 & + \\
9. & PPP 4 & + \\
10. & PPP 5 & + \\
11. & PPP 6 & + \\
12. & PPP 7 & + \\
13. & PPP 8 & + \\
14. & PPP 9 & ++ \\
15. & PPP 10 & + \\
16. & PPP 11 & ++ \\
\hline
\end{tabular}

Keterangan : Resistensi bakteri ditandai dengan keruh atau tidaknya media tumbuh; $++=$ Media tumbuh sangat keruh; + = Media tumbuh keruh

Tabel 3. Persen Degradasi Isolat Bakteri terhadap Pestisida Triazofos 50 ppm.

\begin{tabular}{cccc}
\hline Isolat Bakteri & $\begin{array}{c}\text { Konsentrasi pestisida } \\
\text { sebelum degradasi }(\mathrm{ppm})\end{array}$ & $\begin{array}{c}\text { Konsentrasi pestisida } \\
\text { setelah degradasi (ppm) }\end{array}$ & $\begin{array}{c}\text { Persentasi } \\
\text { Degradasi (\%) }\end{array}$ \\
\hline PPP 11 & 50 & 0,12 & 99,76 \\
PPP 9 & 50 & 0,84 & 98,32 \\
GPP 6 & 50 & 2,18 & 95,64 \\
PPP 1 & 50 & 2,85 & 94,3 \\
GPP 7 & 50 & 19,78 & 60,44 \\
GPP 4 & 50 & 32,83 & 34,34 \\
\hline
\end{tabular}


Uji kualitatif dilakukan untuk mengetahui apakah isolat bakteri yang diuji dapat bertahan hidup dan mendegradasi pestisida triazofos konsentrasi 50 ppm. Hasil uji menunjukkan bahwa seluruh isolat yang digunakan bersifat resisten terhadap pestisida triazofos. Semakin tinggi resistensi pestisida dibuktikan dengan semakin keruhnya media uji yang menandakan kepadatan bakteri sangat tinggi. Kekeruhan yang dihasilkan dari isolat bakteri berbeda-beda, terdapat isolat dengan tingkat kekeruhan yang keruh, dan tidak keruh. Hasil uji kualitatif menunjukkan terdapat 6 isolat tumbuh keruh. Isolat yang menunjukkan hasil keruh yaitu GPP 7, GPP 9, PPP 1 PPP 2, PPP 9 dan PPP 11. Tingkat kekeruhan yang tinggi menyimpulkan bahwa bakteri mampu tumbuh dengan baik pada media zobell cair dan mampu mendegradasi pestisida triazofos dengan konsentrasi 50 ppm. Kekeruhan yang dihasilkan dikarenakan bakteri dapat tumbuh dan berkembang dengan optimal pada media yang dicampur oleh pestisida, hal tersebut sesuai dengan pendapat Rahmansyah \& Sulistinah (2009), yang menyatakan bahwa pestisida yang didegradasi oleh bakteri akan menjadi sumber karbon bagi bakteri untuk bertahan hidup dan berkembang sehingga bakteri akan berjumlah semakin banyak dan media akan semakin keruh. Isolat yang tingkat kekeruhannya kurang baik dapat disebabkan oleh kemampuan adaptasi dari bakteri terhadap lingkungan yang tidak dapat beradaptasi secara optimal. Pestisida triazofos pada umumnya akan bertahan di lingkungan selama 10 hari jika proses degradasi berjalan secara alami tanpa campur tangan manusia.

Uji kuantitatif isolat bakteri untuk mengetahui persentase degradasi isolat bakteri terhadap pestisida triazofos konsentrasi $50 \mathrm{ppm}$. Konsentrasi pestisida triazofos setelah terdegradasi oleh bakteri memiliki hasil yang beraneka ragam. Penurunan konsentrasi terbesar terdapat pada isolat PPP 11 dengan penurunan konsentrasi dari 50 ppm menjadi 0,0102 ppm. Penurunan konsentrasi selanjutnya yaitu isolat PPP 9 dengan penurunan dari 50 ppm menjadi 0,84 ppm. Isolat GPP 6 menjadi isolat ketiga dengan penurunan konsentrasi dari $50 \mathrm{ppm}$ menjadi $2,18 \mathrm{ppm}$. Penurunan konsentrasi terendah terdapat pada isolat PPP 1 dengan hasil dari 50 ppm menjadi 2,85 ppm. Hasil persentase degradasi pestisida menunjukkan isolat GPP 7 mempunyai persen degradasi terbesar dengan 19,78 ppm. Proses degradasi adalah proses terjadinya peruraian pestisida setelah digunakan, dapat terjadi sebagai akibat adanya; mikroba, reaksi kimia, dan sinar matahari. Prosesnya dapat terjadi setiap saat dari hitungan jam, hari, sampai tahunan bergantung pada kondisi lingkungan dan sifat-sifat kimia pestisida (Manuaba, 2009). Bakteri yang tetap bertahan hidup di lingkungan yang mengandung pestisida merupakan ekspresi bakteri yang mampu hidup dan dapat mendegradasi pestisida (Rahmansyah \& Sulistinah, 2009). Proses degradasi tidak hanya dipengaruhi oleh keberadaan faktor biotik saja melainkan terdapat juga faktor abiotik yang diantaranya adalah temperatur $\pm 25^{\circ} \mathrm{C}$, kelembaban, dan $\mathrm{pH}$ lingkungan hidup bakteri dengan kisaran 5,5-8,5 (Leland, 1998).

\section{KESIMPULAN}

Berdasarkan penelitian yang telah dilakukan, dapat disimpulkan bahwa terdapat isolat bakteri asosiasi karang Porites sp. dan Galaxea sp. yang memiliki resistensi terhadap pestisida triazofos Hasil pengamatan kualitatif resistensi bakteri terhadap pestisida menunjukkan bahwa semua isolat bakteri yang diuji bersifat resisten. Isolat bakteri dengan indikator resistensi yang sangat keruh yaitu GGP 7, GPP 9, PPP 1, PPP 2, PPP 9, PPP 11. Persentase degradasi isolat bakteri tertinggi adalah isolat bakteri PPP 11 dan terendah adalah isolat bakteri GPP 4.

\section{UCAPAN TERIMAKASIH}

Penelitian ini merupakan bagian dari skripsi yang berjudul "Isolasi dan Karakterisasi Bakteri Pendegradasi Triazofos dari Karang Porites sp. dan Galaxea sp Sebagai Upaya Bioremediasi Di Perairan Pulau Panjang Jepara" guna memperoleh gelar Sarjana Strata Satu IImu Kelautan Fakultas Perikanan dan IImu Kelautan Universitas Diponegoro

\section{DAFTAR PUSTAKA}

Arfi, F. \& Safni, Z.A. 2015. Degradasi Senyawa Paraquat dalam Pestisida Gramoxone Secara Sinolisis dengan Penambahan ZnO. Lantanida Journal, 3(1):71-81. 
Arikunto, S., 2006. Prosedur Penelitian Revisi IV. Rineka Cipta. Jakarta. 378 hlm

Dahuri, R. 2000. Pendayagunaan Sumberdaya Kelautan Untuk Kesejahteraan Masyarakat. LISPI. Jakarta.

Kamanyire. R. \& Karalliedde, L. 2004. Organophosphate toxicity and occupational exposure. Occupational Medicine, 54:69-75.

Klein, J. \& Alder, L. 2003. Applicability of gradient liquid chromatography with tandem mass spectrometry to the simultaneous screening for about 100 pesticides in crops. Journal of AOAC International, 86:1015- 1037.

Leland, J.E. 1998. Evaluating the Hazard if Land Applying Composted Triazofos Waste Using Earthworm Biomonitoring. Thesis. Faculty of The Virginia Polytechnic Institute and State University, Virginia.

Manuaba, I.B.P. 2009. Cemaran Pestisida Karbamat dalam Air Danau Buyan Buleleng Bali. Jurusan Kimia FMIPA Universitas Udayana: Jurnal Kimia, 3(1):47-54.

Munasik. 2009. Konservasi Terumbu Karang. Badan Penerbit Universitas Diponegoro, Semarang, $117 \mathrm{hlm}$

Nugroho, B.Y.H., Sri, Y.W. \& Ali, R. 2015. Analisis Residu Organofosfat di Perairan Mlonggo Kabupaten Jepara. Jurnal Oseanografi, 4(3):541-544.

Nybakken, J. W. 1992. Biologi Laut : Suatu Pendekatan Ekologis. Gramedia Pustaka Utama, Jakarta. 459.

Permanasari, A. 2011. Spektrofotometri Serapan UV-Vis. http://anna- permanasari.staf.upi.edu/ files/2011/03/Spektro-UV-Vis.pdf.

Rahmansyah, M. \& Sulistinah, N. 2009. Performa Bakteri pada Tanah Tercemar Pestisida. Berita Biologi, 9(5):1-8.

Suharsono, 1996. Jenis-Jenis Karang Yang Umum di Jumpai di Indonesia. P3O-LIPI, Jakarta, 116 hlm.

Taufik, I. 2011. Pencemaran Pestisida pada Perairan Perikanan di Sukabumi Jawa Barat. Media Akuakultur , 6(1) : 69-75. doi: 10.15578/ma.6.1.2011.69-75

Worthing \& Hance, R. 1991. The Pesticide Manual, The British Crop Protection Council, Surrey, pp. 91-92. 